\title{
A meta-analysis of the genome-wide association studies on two genetically correlated phenotypes (self-reported headache and self-reported migraine) identifies four new risk loci for headaches $(\mathrm{N}=397,385)$
}

Weihua Meng ${ }^{1,2 \star}$, Parminder S Reel ${ }^{1}$, Charvi Nangia ${ }^{1}$, Aravind Lathika Rajendrakumar ${ }^{1}$, Harry L Hebert ${ }^{1}$, Mark J Adams ${ }^{3}$, Hua Zheng ${ }^{4}$, Zen Haut Lu ${ }^{5}$, 23andMe Research Team ${ }^{6}$; Debashree Ray $^{7,8}$, Lesley A Colvin ${ }^{1}$, Colin NA Palmer ${ }^{1}$, Andrew Mclntosh ${ }^{3}$, Blair H Smith ${ }^{1}$.

1 Division of Population Health and Genomics, Ninewells Hospital and Medical School, University of Dundee, Dundee, UK, DD2 4BF

2 Department of Biological Sciences, School of Science, Xi'an Jiaotong-Liverpool University, Suzhou, China

3 Division of Psychiatry, Edinburgh Medical School, University of Edinburgh, Edinburgh, UK, $\mathrm{EH} 10 \mathrm{HHF}$

4 Department of Anaesthesiology, Tongji Hospital, Tongji Medical College, Huazhong University of Science and Technology, Wuhan, China

5 PAPRSB Institute of Health Sciences, Universiti Brunei Darussalam, Bandar Seri Begawan, Brunei Darussalam

6 23andMe, Inc., Sunnyvale, CA, USA

7 Department of Epidemiology, Bloomberg School of Public Health, Johns Hopkins University, Baltimore, Maryland, USA

8 Department of Biostatistics, Bloomberg School of Public Health, Johns Hopkins University, Baltimore, Maryland, USA 
medRxiv preprint doi: https://doi.org/10.1101/2021.09.15.21263668; this version posted September 22, 2021. The copyright holder for this preprint (which was not certified by peer review) is the author/funder, who has granted medRxiv a license to display the preprint in perpetuity. It is made available under a CC-BY-NC-ND 4.0 International license .

Corresponding Author: Dr Weihua Meng, Ph.D.

Address: Department of Biological Sciences, School of Science, Xi'an Jiaotong-Liverpool University, Suzhou, China. Tel: +86 512 88161372, Email: weihua.meng@xjtlu.edu.cn

Funding Sources: This study was mainly funded by the Wellcome Trust Strategic Award "Stratifying Resilience and Depression Longitudinally" (STRADL) with reference number 104036/Z/14/Z.

Conflicts of Interest: The employees of 23andMe/23andMe Research Team hold stock in the company. The other authors declare that they have no conflict of interest.

Keywords: headache; migraine; metaUSAT; correlated phenotypes; meta-analysis; genomewide association study

Running head: GWAS meta-analysis on headaches 


\section{Abstract}

Headache is one of the commonest complaints that doctors need to address in clinical settings. The genetic mechanisms of different types of headache are not well understood. In this study, we performed a meta-analysis of genome-wide association studies (GWAS) on the self-reported headache phenotype from the UK Biobank cohort and the self-reported migraine phenotype from the 23andMe resource using the metaUSAT for genetically correlated phenotypes $(\mathrm{N}=397,385)$. We identified 38 loci for headaches, of which 34 loci have been reported before and 4 loci were newly identified. The LRP1-STAT6-SDR9C7 region in chromosome 12 was the most significantly associated locus with a leading $P$ value of $1.24 \times 10^{-62}$ of rs 11172113 . The ONECUT2 gene locus in chromosome 18 was the strongest signal among the 4 new loci with a $P$ value of $1.29 \times 10^{-9}$ of rs673939. Our study demonstrated that the genetically correlated phenotypes of self-reported headache and self-reported migraine can be meta-analysed together in theory and in practice to boost study power to identify more new variants for headaches. This study has paved way for a large GWAS meta-analysis study involving cohorts of different, though genetically correlated headache phenotypes. 
medRxiv preprint doi: https://doi.org/10.1101/2021.09.15.21263668; this version posted September 22, 2021. The copyright holder for this preprint (which was not certified by peer review) is the author/funder, who has granted medRxiv a license to display the preprint in perpetuity.

It is made available under a CC-BY-NC-ND 4.0 International license .

\section{Background}

Headache is one of the commonest symptoms that present to clinicians in general practice or in specialist neurology clinics. (1) Its lifetime prevalence in individuals is as high as $93 \%$. (2) Globally, around $46 \%$ of the adult population suffers with an active headache disorder. (3) According to the current definitions of the International Headache Society, headaches can be classified into three categories: 1. primary headaches (including migraine, tension-type headache, and trigeminal autonomic cephalalgias); 2. secondary headaches (including headaches attributed to other disorders such as trauma, infection); 3. painful cranial neuropathies, other facial pain and other headaches. (4)

Among all types of headache, tension-type headache is the commonest form, causing over $40 \%$ of all headaches in the general population, while migraine is the most disabling type at population level, with a prevalence of around $10 \%$ of all headaches. (5) It is important to note that an individual can experience more than one type of headache at the same time. (1)

According to the Global Burden of Diseases 2019 study, headache disorders represent the 14th leading cause of disability-adjusted life years (DALYs) when considering all ages and both genders. (6) As the definition of the headache disorders in this study only included migraine and tension type headache, it is reasonable to assume that the real impact of all types of headaches in the world is much more significant. It was estimated in 2003 that migraine alone cost the UK over £2bn a year. (7) Migraine is still one of the leading causes of disability among over 300 diseases. (8)

It has been confirmed that headaches such as migraine are heritable. The single nucleotide polymorphism (SNP) based-heritabilities of migraine and self-reported headache were 0.15 and 0.21 in Caucasians, respectively. $(9,10)$ Genome-wide association studies (GWAS) have revealed that there are significant genetic components contributing to migraine. (11-15) $\mathrm{A}$ 
medRxiv preprint doi: https://doi.org/10.1101/2021.09.15.21263668; this version posted September 22, 2021. The copyright holder for this preprint (which was not certified by peer review) is the author/funder, who has granted medRxiv a license to display the preprint in perpetuity.

It is made available under a CC-BY-NC-ND 4.0 International license.

GWAS meta-analysis paper consisting of 22 cohorts by Gormley et al identified 38 genetic loci for migraine. (9) Our study based on the UK Biobank resource also revealed 28 risk loci for selfreported headache, of which 14 loci had been previously identified by Gormley et al and 14 loci were newly reported. (10)

Recently, researchers have been encouraged to perform GWAS meta-analysis on genetically correlated phenotypes, due to the increasing recognition of pleiotropy in GWAS, to boost study power to detect more genetic components. (16) Pleiotropy refers to the phenomenon where a genetic variant or a gene has non-zero effect on multiple phenotypic traits, and can contribute to genetic correlations among these traits. (17) Successful examples of recent GWAS metaanalysis studies on genetically correlated phenotypes have included education and intelligence as well as different hypertension phenotypes. $(18,19)$

In a previous study, we reported that the self-reported headache phenotype from the UK Biobank and the self-reported migraine phenotype from the 23andMe were genetically correlated, with a high correlation value of 0.72 . (20) Therefore, we aimed to perform a joint GWAS meta-analysis study of these two different but highly genetically correlated phenotypes with a view to replicating previously identified genetic associations and identifying new associations arising from the increased power of this approach.

\section{Methods}

\section{Cohorts' information:}

The two sets of GWAS summary statistics used in this study were from the GWAS on selfreported headache based on the UK Biobank cohort and the GWAS on self-reported migraine provided by the 23andMe. $(9,10)$ 
medRxiv preprint doi: https://doi.org/10.1101/2021.09.15.21263668; this version posted September 22, 2021. The copyright holder for this preprint (which was not certified by peer review) is the author/funder, who has granted medRxiv a license to display the preprint in perpetuity.

It is made available under a CC-BY-NC-ND 4.0 International license .

The definitions of self-reported headache (UK Biobank) were: cases ( $N=74,461)$, defined as those who self-reported headache symptoms affecting daily lives within last month using the UK Biobank online questionnaire; controls $(\mathrm{N}=149,312)$, defined as those who did not have any pain affecting daily lives within last month. The corresponding GWAS analysis was performed using a linear mixed model adjusting for age, sex, nine population principal components, genotyping arrays, and assessment centers (10). The dataset contains 9,304,965 SNPs (minor allele frequency $>0.005$, imputation score $>0.1$ ).

The definitions of self-reported migraine (23andMe) were: cases $(\mathrm{N}=30,465)$, defined as those who self-reported a migraine history (diagnosed by doctors or self-diagnosing) using the 23andMe online questionnaire; controls $(N=143,147)$, those who self-reported having no migraine. The corresponding GWAS was performed using a linear mixed model adjusting for age, sex, and five population principal components (9). The dataset contains $19,023,436$ SNPs (containing minor allele frequency and imputation score information for all SNPs).

All of the participants in both GWAS were of European descent. In addition, as the UK Biobank cohort only recruited within the UK, while the 23 andMe mainly recruited from the USA, there was little sample overlap between the two cohorts (linkage disequilibrium score regression intercept $=0.009)$. (20) The detailed cohorts' information and the statistical methods of the two GWAS can be found in the original papers. $(9,10)$.

\section{The preprocessing of the GWAS summary statistics:}

SNPs in both datasets were coded in a forward direction and according to the GRCh37 genome build. In total, $8,500,802$ SNPs with minor allele frequency $>0.005$ and common to both datasets were extracted. To ensure the datasets could be jointly meta-analysed, these SNPs were checked for same effect alleles and flipped accordingly in R (https://www.r-project.org/). 
medRxiv preprint doi: https://doi.org/10.1101/2021.09.15.21263668; this version posted September 22, 2021. The copyright holder for this preprint (which was not certified by peer review) is the author/funder, who has granted medRxiv a license to display the preprint in perpetuity.

It is made available under a CC-BY-NC-ND 4.0 International license .

\section{The meta-analysis method:}

MetaUSAT (Unified Score-based Association Test) is a software package for performing GWAS meta-analysis studies on genetically correlated phenotypes. (https://github.com/RayDebashree/metaUSAT) MetaUSAT applies a multivariate meta-analysis approach instead of a univariate approach of analysing each related trait separately. Unlike traditional GWAS meta-analysis on a single trait, where several sets of summary statistics on a single trait are combined into a single summary measure for that trait, the multivariate metaanalysis implemented by metaUSAT does not combine the summary statistics; instead, a joint analysis is performed using summary statistics from related traits. It is a statistical inference approach that leverages related traits to provide a $P$ value for the test of no association of any trait with a SNP against the alternative that at least one trait is associated with the SNP. Being a complex data-adaptive approach, metaUSAT does not output an overall effect size (Beta) and standard error (SE) values for each SNP. MetaUSAT is robust to the association structure of correlated traits and to potential sample overlap. (21)

\section{The annotation method:}

The output generated from metaUSAT was uploaded to FUMA v1.3.6b for SNP annotation. (22) FUMA also generates a Manhattan plot and a corresponding Q-Q plot for the meta-analysis result (https://fuma.ctglab.nl/). FUMA uses "maximum distance of linkage disequilibrium (LD) blocks to merge" (default value $=250 \mathrm{~kb}$ ) to determine the number of associated loci and the $\mathrm{r}^{2}$ value (default value $r^{2} \geq 0.6$ to be considered as non-independent) to determine the number of independent significant SNPs. In addition, the gene-based association analysis and the geneset analysis were performed with MAGMA v1.08, which was integrated in FUMA. (23) In genebased association analysis, summary statistics of SNPs were aggregated to the level of whole genes, testing the joint association of all SNPs in the gene with the phenotype. In other words, all the SNPs were mapped to 19,436 protein coding genes if the SNPs are located within genes. 
medRxiv preprint doi: https://doi.org/10.1101/2021.09.15.21263668; this version posted September 22, 2021. The copyright holder for this preprint (which was not certified by peer review) is the author/funder, who has granted medRxiv a license to display the preprint in perpetuity.

It is made available under a CC-BY-NC-ND 4.0 International license .

In gene-set analysis, individual genes were aggregated to groups of genes sharing certain biological, functional or other characteristics. This was done to provide insight into the involvement of specific biological pathways or cellular functions in the genetic aetiology of a phenotype. A total of 10,894 gene sets were tested and a competitive test model was applied. Tissue expression analysis was obtained from GTEx (https://www.gtexportal.org/home/) which was also integrated in FUMA. In the tissue expression analysis, average gene-expression per tissue type was used as gene covariate to test positive relationships between gene expression in a specific tissue type and genetic associations. In addition, regional plots of the identified new loci were generated by LozusZoom. (http://locuszoom.org/)

\section{Results:}

There were 8,500,802 common SNPs from both cohorts analysed by the metaUSAT software. FUMA reported 38 independent genetic loci across autosomal chromosomes with the LRP1STAT6-SDR9C7 region in chromosome $12 \mathrm{q} 13.3$ being the most significantly associated locus with a leading $P$ value of $1.24 \times 10^{-62}$ for rs 11172113. The FHL5-UFL1 locus in chromosome 6q16.1 was the second most significantly associated, with a $P$ value of $6.57 \times 10^{-39}$ for rs9486715. A Manhattan plot showing these loci is shown in Figure 1. A corresponding $Q-Q$ plot is included as Supplementary Figure 1. Among the 38 identified loci, there were 7,952 SNPs that demonstrated an association with genome-wide significance, with $P$ value $<5 \times 10^{-8}$. Among these SNPs, 133 SNPs were considered as independent associations $\left(r^{2}<0.6\right.$ with any SNP within the 7,952 SNPs). (Supplementary Table 1 and 2)

Table 1 summarises the information relating to the 38 associated loci. Among these loci, 25 loci had previously been reported by Gormley et al and 9 further loci had been separately identified by Meng et al $(14,15)$. Four of the 38 loci were newly identified. The ONECUT2 gene locus (18q21.31) was the strongest signal among these 4 new loci, associated with a $P$ value of 1.29 
medRxiv preprint doi: https://doi.org/10.1101/2021.09.15.21263668; this version posted September 22, 2021. The copyright holder for this preprint (which was not certified by peer review) is the author/funder, who has granted medRxiv a license to display the preprint in perpetuity.

It is made available under a CC-BY-NC-ND 4.0 International license .

$\times 10^{-9}$ for rs673939. Table 2 summarises the details of the 4 newly identified loci. Regional plots of these 4 new loci are included as Figure 2.

The gene-based association study identified 51 genes (cut-off $P$ value $=0.05 / 19,436=2.57 x$ $10^{-6}$ ) that were associated with headaches, with the PRDM16 gene showing the strongest association $\left(P\right.$ value of $\left.7.10 \times 10^{-15}\right)$. All significantly associated genes are summarised in Supplementary Table 3.

The gene-set analysis found that no specific pathway was significantly associated with headaches after Bonferroni correction (cut-off $P$ value $=0.05 / 10,894=4.6 \times 10^{-6}$ ). The top 10 pathways are included in the Supplementary Table 4.

Two types of tissue analysis were performed. The tissue expression analysis on 30 general tissues revealed that both brain tissues and vascular tissues are potentially involved in the disease mechanisms (Figure 3). The tissue expression analysis on 54 specific tissues also found 11 brain tissues with significant association $\left(P<0.05 / 54=9.26 \times 10^{-4}\right)$ (Figure 4).

\section{Discussion}

We performed a GWAS meta-analysis study on two highly genetically correlated phenotypes based on summary statistics from two large GWAS: self-reported headache and self-reported migraine (genetic correlation value $=0.72$ ). This analysis identified 38 loci associated with headaches, of which 34 had been previously identified $(9,10)$ and 4 were newly identified loci.

GWAS on complex traits have achieved great success in the past decade. (24) Furthermore, GWAS meta-analysis on same phenotypes from multi-centers and multi-cohorts also improve statistical power to identify genetic variants which otherwise cannot be detected by a single cohort study. (25) However, the number of cohorts in a genetic consortium will reach a bottleneck when most of the existing cohorts are already included. It becomes more difficult to 
medRxiv preprint doi: https://doi.org/10.1101/2021.09.15.21263668; this version posted September 22, 2021. The copyright holder for this preprint (which was not certified by peer review) is the author/funder, who has granted medRxiv a license to display the preprint in perpetuity.

It is made available under a CC-BY-NC-ND 4.0 International license .

include extra cohorts into the consortium to achieve a higher study power. Meanwhile, it might also be challenging to fund and allocate resources to increase sample size of cohorts in a genetic consortium. This has led to the development and use of statistical methods that leverage other aspects of a study to increase detection power. Software developed for joint meta-analysis of GWAS on existing correlated phenotypes can improve power with minimum additional resource requirement, particularly as it is now a routine requirement for GWAS summary statistics to be shared publicly after publication. (26). Specific software created for this purpose includes META-SCOPA and metaCCA. $(27,28)$

In this study, we used a recently developed software called metaUSAT, whose properties have been illustrated using simulated data, and the T2D-GENES and the METSIM datasets. $(29,30)$ The software does not generate an overall Beta or standard error for each SNP but it calculates a $Z$ value representing the contribution of each SNP from each cohort or each phenotype. As with Beta values, if $Z$ values are both positive or both negative, then the direction of the SNP effect on the traits is the same. In Table 2, we see that the most strongly associated SNPs in the top nine loci all have the same direction of effect. However, the lead SNP in the LINC02210CRHR1-MAPT locus (ranked $10^{\text {th }}$ ), although highly significantly associated, showed a different direction of effect in the two datasets. This might indicate that the role of this locus might be different in these two phenotypes. Comparing the Z-values could be a novel way to differentiate the genetic impact of certain SNPs in genetically correlated yet different phenotypes. (31)

Consistent with previous studies, the most significantly associated locus in the LRP1-STAT6SDR9C7 region was the strongest locus identified in the meta-analysis $\left(P=1.24 \times 10^{-62}\right.$ for rs11172113). $(9,10)$ This locus, ranging from $57,244,168$ to $57,629,608$ in chromosome 12 , contained 122 SNPs associated with genome-wide significance, among the 166 SNPs in the output dataset. The $L R P 1$ gene has been well established as a migraine gene. $(11,12)$ One theory about its possible link with migraine is that the LRP1 protein interacts with the glutamate 
medRxiv preprint doi: https://doi.org/10.1101/2021.09.15.21263668; this version posted September 22, 2021. The copyright holder for this preprint (which was not certified by peer review) is the author/funder, who has granted medRxiv a license to display the preprint in perpetuity.

It is made available under a CC-BY-NC-ND 4.0 International license .

receptors on neurons while the pathophysiology of migraine has been suggested to be related with the glutamate homeostasis. (32) The gene-based association study revealed that the PRDM16 gene was the most significantly associated gene, followed by CRHR1, MAPT, and KANSL1 (Supplementary Table 3). Through the tissue expression analysis, both brain and vascular tissues were indicated as being involved in the mechanisms of headaches. Gormley et al found that vascular factors played a main role in migraine (9), while in our UK Biobank study, we found that neural tissues were major factors in self-reported headache. We therefore deduce that for other types of headaches, such as tension-type headache which produce most headaches in the general population, the role of neural tissue is likely to be greater than that of vascular factors.

In this study, we found 4 new loci which have not previously been reported to be associated with headaches. The ONECUT2 gene region was the most strongly associated among these 4 loci. The $Z$ values from the headache study $(Z=-5.24)$ and the migraine study $(Z=-4.05)$ were in the same direction. The original $P$ values of the top SNP (rs673939) in this region were $9.00 \mathrm{x}$ $10^{-8}$ in the Meng et al study (10) and $4.88 \times 10^{-5}$ in the 23 andMe migraine dataset (9). The ONECUT2 gene, also termed OC 72 , is a newly discovered member of the ONECUT transcription factor family. (33) ONECUT2 can widely regulate the protein expression associated with cell proliferation, migration, adhesion and differentiation, thus being involved in the regulation of the development of an organism. (34) It has been well reported for its associations with multiple cancers. Although we do not know why it is statistically associated with headaches, the gene is expressed in the brain. (https://www.ncbi.nlm.nih.gov/gene/9480) it is not uncommon that SNPs can be associated with multiple phenotypes which seem completely unrelated. (35) MAU2 is a protein-coding gene, which plays an important role when cohesins (chromosome-associated multi-subunit protein complex) try to bind to DNA to carry out a large spectrum of chromatin-related functions, including sister chromatid cohesion, DNA repair, 
medRxiv preprint doi: https://doi.org/10.1101/2021.09.15.21263668; this version posted September 22, 2021. The copyright holder for this preprint (which was not certified by peer review) is the author/funder, who has granted medRxiv a license to display the preprint in perpetuity.

It is made available under a CC-BY-NC-ND 4.0 International license .

transcriptional regulation, and three-dimensional organization of chromatin. (36) Mutations of MAU2 have been linked with a rare disorder of Cornelia de Lange Syndrome. (37) KCNK17 is the nearest gene to the leading SNP of rs72854120 in the third new locus. Variants of this gene have been reported to be associated with ischaemic stroke, cerebral hemorrhage and arrhythmia. $(38,39)$ The protein products of ZNF462 have shown important roles in embryonic development in animal models. (40) Variants of this gene have been reported to contribute to craniofacial and neurodevelopmental abnormalities. (41) It is worth noting that the $Z$ values of each leading SNP in the 4 new loci were all in the same direction in each of the two cohorts.

Although we were successful in performing this study, researchers need to be note that we had particular advantages in this study. One was that the two phenotypes are highly genetically correlated. If the two phenotypes are not so highly correlated, the ability of a study to detect more new variants would be reduced. Secondly, our two cohorts were both of mainly European descent and with minimum sample overlap; therefore, we avoided some negative impact (such as increasing type I and type II errors) which could be caused by these factors in the study.

It is also important to note that the control definitions in the two GWAS datasets were different. The controls used in the UK Biobank self-reported headache phenotype reported no pain within previous month, while the controls used in the 23 andMe self-reported migraine phenotype could have had pain in body sites other than the head. This mean that genes identified in the UK Biobank cohort may not be specific to headache, but could be more generally associated with pain.

In summary, our study identified 4 new genetic loci which are associated with self-reported headaches and/or migraine, and shed further light on their potential mechanisms. Further research could attempt a meta-analysis study on GWAS of different types of primary headaches (on the condition that they are reasonably genetically correlated) to identify further genetic components. 


\section{Funding}

This work was supported by the STRADL project [Wellcome Trust, grant number: 104036/Z/14/Z]. The funders had no role in study design, data collection, data analysis, interpretation, writing of the report.

\section{Conflict of interest}

The employees of 23andMe/23andMe Research Team hold stock in the company. The other authors declare that they have no conflict of interest.

\section{Acknowledgements}

The current study was conducted under approved UK Biobank data application number 4844. We would like to thank all participants of the UK Biobank cohort who have provided necessary genetic and phenotypic information. We would like to thank the research participants and employees of 23 andMe for making this work possible.

\section{3andMe Consortium}

The following members of the 23andMe Research Team contributed to this study: Stella Aslibekyan, Adam Auton, Elizabeth Babalola, Robert K. Bell, Jessica Bielenberg, Katarzyna Bryc, Emily Bullis, Daniella Coker, Gabriel Cuellar Partida, Devika Dhamija, Sayantan Das, Sarah L. Elson, Teresa Filshtein, Kipper Fletez-Brant, Pierre Fontanillas, Will Freyman, Anna Faaborg, Shirin T. Fuller, Pooja M. Gandhi, Karl Heilbron, Barry Hicks, Ethan M. Jewett, Katelyn Kukar, Keng-Han Lin, Maya Lowe, Jey C. McCreight, Matthew H. Mclntyre, Steven J. Micheletti, Meghan E. Moreno, Joanna L. Mountain, Priyanka Nandakumar, Elizabeth S. Noblin, Jared O'Connell, Yunru Huang, Aaron A. Petrakovitz, Vanessa Lane, Aaron Petrakovitz, Joanne S. Kim, G. David Poznik, Morgan Schumacher, Anjali J. Shastri, Janie F. Shelton, Jingchunzi Shi, 
medRxiv preprint doi: https://doi.org/10.1101/2021.09.15.21263668; this version posted September 22, 2021. The copyright holder for this preprint (which was not certified by peer review) is the author/funder, who has granted medRxiv a license to display the preprint in perpetuity.

It is made available under a CC-BY-NC-ND 4.0 International license .

Suyash Shringarpure, Vinh Tran, Joyce Y. Tung, Xin Wang, Wei Wang, Catherine H. Weldon, Peter Wilton, Alejandro Hernandez, Corinna Wong, Christophe Toukam Tchakouté.

\section{Data availability}

The GWAS meta-analysis summary statistics can be downloaded from https://app.box.com/s/gm2qkf17hc9w1fc5ymvifgbxz0httvhs

The FUMA results can be viewed from

\section{https://fuma.ctglab.nl/browse/334.}

Data from 23andMe were obtained under a data transfer agreement. Further information about obtaining access to the 23andMe Inc. summary statistics is available from: https://research.23andme.com/collaborate/. Any other data relevant to the study that are not included in the article or its supplementary materials are available from the authors upon reasonable request.

\section{Author contribution}

W.M. organised project, drafted the paper and contributed to the analysis. P.S.R., C.N. and A.L.R. performed the meta-analysis. H.H. contributed to Table 1. M.J.A. performed the UK Biobank GWAS analysis. H.Z. and Z.H.L. contributed to discussion parts. The 23andMe Research Team provided the GWAS summary statistics of the 23andMe cohort. D.R. supervised the usage of the metaUSAT software and provided comments. L.C. and C.N.A.P. provided comments to the paper. A.M. and B.H.S. organised the project and provided comments.

\section{References}

1. Fuller G, Kaye C. Headaches. BMJ. 2007;334:254-6. 
2. Boardman HF, Thomas E, Croft PR, Millson DS. Epidemiology of headache in an English district. Cephalalgia. 2003;23:129-37.

3. Stovner Lj, Hagen K, Jensen R, Katsarava Z, Lipton R, Scher A, Steiner T, Zwart JA. The global burden of headache: a documentation of headache prevalence and disability worldwide. Cephalalgia. 2007;27:193-210.

4. Headache Classification Committee of the International Headache Society (IHS) The International Classification of Headache Disorders, 3rd edition. Cephalalgia. 2018;38:1211.

5. Riesco N, Cernuda-Morollón E, Pascual J. Neuropeptides as a Marker for Chronic Headache. Curr Pain Headache Rep. 2017;21:18.

6. GBD 2019 Diseases and Injuries Collaborators. Global burden of 369 diseases and injuries in 204 countries and territories, 1990-2019: a systematic analysis for the Global Burden of Disease Study 2019. Lancet. 2020;396:1204-22.

7. Steiner TJ, Scher AI, Stewart WF, Kolodner K, Liberman J, Lipton RB. The prevalence and disability burden of adult migraine in England and their relationships to age, gender and ethnicity. Cephalalgia. 2003;23:519-27.

8. Steiner TJ, Stovner LJ, Jensen R, Uluduz D, Katsarava Z; Lifting The Burden: the Global Campaign against Headache. Migraine remains second among the world's causes of disability, and first among young women: findings from GBD2019. J Headache Pain. 2020;21:137.

9. Gormley P, Anttila V, Winsvold BS, Palta P, Esko T, Pers TH, Farh KH, Cuenca-Leon E, Muona M, Furlotte NA, Kurth T, Ingason A, McMahon G, Ligthart L, Terwindt GM, Kallela M, Freilinger TM, Ran C, Gordon SG, Stam AH, Steinberg S, Borck G, Koiranen M, Quaye L, Adams HH, Lehtimäki T, Sarin AP, Wedenoja J, Hinds DA, Buring JE, Schürks M, Ridker PM, Hrafnsdottir MG, Stefansson H, Ring SM, Hottenga JJ, Penninx BW, Färkkilä M, Artto V, Kaunisto M, Vepsäläinen S, Malik R, Heath AC, Madden PA, Martin NG, Montgomery GW, Kurki MI, Kals M, Mägi R, Pärn K, Hämäläinen E, Huang $H$, Byrnes AE, Franke L, Huang J, Stergiakouli E, Lee PH, Sandor C, Webber C, Cader Z, Muller-Myhsok B, Schreiber S, Meitinger T, Eriksson JG, Salomaa V, Heikkilä K, Loehrer E, Uitterlinden AG, Hofman A, van Duijn CM, Cherkas L, Pedersen LM, Stubhaug A, Nielsen CS, Männikkö M, Mihailov E, Milani L, Göbel H, Esserlind AL, Christensen AF, Hansen TF, Werge T; International Headache Genetics Consortium, Kaprio J, Aromaa AJ, Raitakari O, Ikram MA, Spector T, Järvelin MR, Metspalu A, Kubisch C, Strachan DP, Ferrari MD, Belin AC, Dichgans M, Wessman M, van den Maagdenberg AM, Zwart JA, Boomsma DI, Smith GD, Stefansson K, Eriksson N, Daly MJ, Neale BM, Olesen J, Chasman DI, Nyholt DR, Palotie A. Meta-analysis of 375,000 individuals identifies 38 susceptibility loci for migraine. Nat Genet. 2016;48:856-66.

10. Meng W, Adams MJ, Hebert HL, Deary IJ, Mclntosh AM, Smith BH. A Genome-Wide Association Study Finds Genetic Associations with Broadly-Defined Headache in UK Biobank (N=223,773). EBioMedicine. 2018;28:180-6.

11. Anttila V, Stefansson H, Kallela M, Todt U, Terwindt GM, Calafato MS, Nyholt DR, Dimas AS, Freilinger T, Müller-Myhsok B, Artto V, Inouye M, Alakurtti K, Kaunisto MA, Hämäläinen $E$, de Vries B, Stam AH, Weller CM, Heinze A, Heinze-Kuhn K, Goebel I, Borck G, Göbel H, Steinberg S, Wolf C, Björnsson A, Gudmundsson G, Kirchmann M, Hauge A, Werge T, Schoenen J, Eriksson JG, Hagen K, Stovner L, Wichmann HE, Meitinger T, Alexander M, Moebus S, Schreiber S, Aulchenko YS, Breteler MM, Uitterlinden AG, Hofman A, van Duijn CM, Tikka-Kleemola P, Vepsäläinen S, Lucae S, 
Tozzi F, Muglia P, Barrett J, Kaprio J, Färkkilä M, Peltonen L, Stefansson K, Zwart JA, Ferrari MD, Olesen J, Daly M, Wessman M, van den Maagdenberg AM, Dichgans $M$, Kubisch C, Dermitzakis ET, Frants RR, Palotie A; International Headache Genetics Consortium. Genome-wide association study of migraine implicates a common susceptibility variant on 8q22.1. Nat Genet. 2010;42:869-73.

12. Anttila V, Winsvold BS, Gormley P, Kurth T, Bettella F, McMahon G, Kallela M, Malik R, de Vries B, Terwindt G, Medland SE, Todt U, McArdle WL, Quaye L, Koiranen M, Ikram MA, Lehtimäki T, Stam AH, Ligthart L, Wedenoja J, Dunham I, Neale BM, Palta P, Hamalainen E, Schürks M, Rose LM, Buring JE, Ridker PM, Steinberg S, Stefansson H, Jakobsson F, Lawlor DA, Evans DM, Ring SM, Färkkilä M, Artto V, Kaunisto MA, Freilinger T, Schoenen J, Frants RR, Pelzer N, Weller CM, Zielman R, Heath AC, Madden PAF, Montgomery GW, Martin NG, Borck G, Göbel H, Heinze A, Heinze-Kuhn K, Williams FMK, Hartikainen AL, Pouta A, van den Ende J, Uitterlinden AG, Hofman A, Amin N, Hottenga JJ, Vink JM, Heikkilä K, Alexander M, Muller-Myhsok B, Schreiber S, Meitinger T, Wichmann HE, Aromaa A, Eriksson JG, Traynor B, Trabzuni D; North American Brain Expression Consortium; UK Brain Expression Consortium, Rossin E, Lage K, Jacobs SBR, Gibbs JR, Birney E, Kaprio J, Penninx BW, Boomsma DI, van Duijn C, Raitakari O, Jarvelin MR, Zwart JA, Cherkas L, Strachan DP, Kubisch C, Ferrari MD, van den Maagdenberg AMJM, Dichgans M, Wessman M, Smith GD, Stefansson K, Daly MJ, Nyholt DR, Chasman D, Palotie A. Genome-wide meta-analysis identifies new susceptibility loci for migraine. Nat Genet. 2013;45:912-7.

13. Chasman DI, Schürks M, Anttila V, de Vries B, Schminke U, Launer LJ, Terwindt GM, van den Maagdenberg AM, Fendrich K, Völzke H, Ernst F, Griffiths LR, Buring JE, Kallela M, Freilinger T, Kubisch C, Ridker PM, Palotie A, Ferrari MD, Hoffmann W, Zee RY, Kurth T. Genome-wide association study reveals three susceptibility loci for common migraine in the general population. Nat Genet. 2011;43:695-8.

14. Freilinger T, Anttila V, de Vries B, Malik R, Kallela M, Terwindt GM, Pozo-Rosich P, Winsvold B, Nyholt DR, van Oosterhout WP, Artto V, Todt U, Hämäläinen E, FernándezMorales J, Louter MA, Kaunisto MA, Schoenen J, Raitakari O, Lehtimäki T, Vila-Pueyo M, Göbel H, Wichmann E, Sintas C, Uitterlinden AG, Hofman A, Rivadeneira F, Heinze A, Tronvik E, van Duijn CM, Kaprio J, Cormand B, Wessman M, Frants RR, Meitinger T, Müller-Myhsok B, Zwart JA, Färkkilä M, Macaya A, Ferrari MD, Kubisch C, Palotie A, Dichgans M, van den Maagdenberg AM; International Headache Genetics Consortium. Genome-wide association analysis identifies susceptibility loci for migraine without aura. Nat Genet. 2012;44:777-82.

15. Ligthart L, de Vries B, Smith AV, Ikram MA, Amin N, Hottenga JJ, Koelewijn SC, Kattenberg VM, de Moor MH, Janssens AC, Aulchenko YS, Oostra BA, de Geus EJ, Smit JH, Zitman FG, Uitterlinden AG, Hofman A, Willemsen G, Nyholt DR, Montgomery GW, Terwindt GM, Gudnason V, Penninx BW, Breteler M, Ferrari MD, Launer LJ, van Duijn CM, van den Maagdenberg AM, Boomsma DI. Meta-analysis of genome-wide association for migraine in six population-based European cohorts. Eur J Hum Genet. 2011;19:901-7.

16. Masotti M, Guo B, Wu B. Pleiotropy informed adaptive association test of multiple traits using genome-wide association study summary data. Biometrics. 2019;75:1076-1085.

17. Stearns FW. One hundred years of pleiotropy: a retrospective. Genetics. 2010;186:76773. 
18. Hill WD, Marioni RE, Maghzian O, Ritchie SJ, Hagenaars SP, McIntosh AM, Gale CR, Davies G, Deary IJ. A combined analysis of genetically correlated traits identifies 187 loci and a role for neurogenesis and myelination in intelligence. Mol Psychiatry. 2019;24:169-81.

19. Zhu X, Feng T, Tayo BO, Liang J, Young JH, Franceschini N, Smith JA, Yanek LR, Sun YV, Edwards TL, Chen W, Nalls M, Fox E, Sale M, Bottinger E, Rotimi C; COGENT BP Consortium, Liu Y, McKnight B, Liu K, Arnett DK, Chakravati A, Cooper RS, Redline S. Meta-analysis of correlated traits via summary statistics from GWASs with an application in hypertension. Am J Hum Genet. 2015;96:21-36.

20. Meng W, Adams MJ, Reel P, Rajendrakumar A, Huang Y, Deary IJ, Palmer CNA, McIntosh AM, Smith BH. Genetic correlations between pain phenotypes and depression and neuroticism. Eur J Hum Genet. 2020;28:358-66.

21. Ray D, Boehnke M. Methods for meta-analysis of multiple traits using GWAS summary statistics. Genet Epidemiol. 2018;42:134-45.

22. Watanabe K, Taskesen E, van Bochoven A, Posthuma D. Functional mapping and annotation of genetic associations with FUMA. Nat Commun. 2017;8:1826.

23. de Leeuw CA, Mooij JM, Heskes T, Posthuma D. MAGMA: generalized gene-set analysis of GWAS data. PLoS Comput Biol. 2015;11:e1004219.

24. Mills MC, Rahal C. A scientometric review of genome-wide association studies. Commun Biol. 2019;2:9.

25. Evangelou E, loannidis JP. Meta-analysis methods for genome-wide association studies and beyond. Nat Rev Genet. 2013;14:379-89.

26. Guo B, Wu B. Powerful and efficient SNP-set association tests across multiple phenotypes using GWAS summary data. Bioinformatics. 2019;35:1366-72.

27. Mägi R, Suleimanov YV, Clarke GM, Kaakinen M, Fischer K, Prokopenko I, Morris AP. SCOPA and META-SCOPA: software for the analysis and aggregation of genome-wide association studies of multiple correlated phenotypes. BMC Bioinformatics. 2017;18(1):25.

28. Cichonska A, Rousu J, Marttinen P, Kangas AJ, Soininen P, Lehtimäki T, Raitakari OT, Järvelin MR, Salomaa V, Ala-Korpela M, Ripatti S, Pirinen M. metaCCA: summary statistics-based multivariate meta-analysis of genome-wide association studies using canonical correlation analysis. Bioinformatics. 2016;32:1981-9.

29. Fuchsberger C, Flannick J, Teslovich TM, Mahajan A, Agarwala V, Gaulton KJ, Ma C, Fontanillas P, Moutsianas L, McCarthy DJ, Rivas MA, Perry JRB, Sim X, Blackwell TW, Robertson NR, Rayner NW, Cingolani P, Locke AE, Tajes JF, Highland HM, Dupuis J, Chines PS, Lindgren CM, Hartl C, Jackson AU, Chen H, Huyghe JR, van de Bunt $M$, Pearson RD, Kumar A, Müller-Nurasyid M, Grarup N, Stringham HM, Gamazon ER, Lee J, Chen Y, Scott RA, Below JE, Chen P, Huang J, Go MJ, Stitzel ML, Pasko D, Parker SCJ, Varga TV, Green T, Beer NL, Day-Williams AG, Ferreira T, Fingerlin T, Horikoshi M, Hu C, Huh I, Ikram MK, Kim BJ, Kim Y, Kim YJ, Kwon MS, Lee J, Lee S, Lin KH, Maxwell TJ, Nagai Y, Wang X, Welch RP, Yoon J, Zhang W, Barzilai N, Voight BF, Han BG, Jenkinson CP, Kuulasmaa T, Kuusisto J, Manning A, Ng MCY, Palmer ND, Balkau B, Stančáková A, Abboud HE, Boeing H, Giedraitis V, Prabhakaran D, Gottesman O, Scott J, Carey J, Kwan P, Grant G, Smith JD, Neale BM, Purcell S, Butterworth AS, Howson JMM, Lee HM, Lu Y, Kwak SH, Zhao W, Danesh J, Lam VKL, Park KS, Saleheen D, So WY, Tam CHT, Afzal U, Aguilar D, Arya R, Aung T, Chan E, Navarro C, Cheng CY, Palli D, Correa A, Curran JE, Rybin D, Farook VS, Fowler SP, Freedman BI, 
Griswold M, Hale DE, Hicks PJ, Khor CC, Kumar S, Lehne B, Thuillier D, Lim WY, Liu J, van der Schouw YT, Loh M, Musani SK, Puppala S, Scott WR, Yengo L, Tan ST, Taylor HA Jr, Thameem F, Wilson G Sr, Wong TY, Njølstad PR, Levy JC, Mangino M, Bonnycastle LL, Schwarzmayr T, Fadista J, Surdulescu GL, Herder C, Groves CJ, Wieland T, Bork-Jensen J, Brandslund I, Christensen C, Koistinen HA, Doney ASF, Kinnunen L, Esko T, Farmer AJ, Hakaste L, Hodgkiss D, Kravic J, Lyssenko V, Hollensted M, Jørgensen ME, Jørgensen T, Ladenvall C, Justesen JM, Käräjämäki A, Kriebel J, Rathmann W, Lannfelt L, Lauritzen T, Narisu N, Linneberg A, Melander O, Milani L, Neville M, Orho-Melander M, Qi L, Qi Q, Roden M, Rolandsson O, Swift A, Rosengren AH, Stirrups K, Wood AR, Mihailov E, Blancher C, Carneiro MO, Maguire J, Poplin R, Shakir K, Fennell T, DePristo M, de Angelis MH, Deloukas P, Gjesing AP, Jun G, Nilsson P, Murphy J, Onofrio R, Thorand B, Hansen T, Meisinger C, Hu FB, Isomaa B, Karpe F, Liang L, Peters A, Huth C, O'Rahilly SP, Palmer CNA, Pedersen O, Rauramaa R, Tuomilehto J, Salomaa V, Watanabe RM, Syvänen AC, Bergman RN, Bharadwaj D, Bottinger EP, Cho YS, Chandak GR, Chan JCN, Chia KS, Daly MJ, Ebrahim SB, Langenberg C, Elliott P, Jablonski KA, Lehman DM, Jia W, Ma RCW, Pollin TI, Sandhu M, Tandon N, Froguel P, Barroso I, Teo YY, Zeggini E, Loos RJF, Small KS, Ried JS, DeFronzo RA, Grallert H, Glaser B, Metspalu A, Wareham NJ, Walker M, Banks E, Gieger C, Ingelsson E, Im HK, Illig T, Franks PW, Buck G, Trakalo J, Buck D, Prokopenko I, Mägi R, Lind L, Farjoun Y, Owen KR, Gloyn AL, Strauch K, Tuomi T, Kooner JS, Lee JY, Park T, Donnelly P, Morris AD, Hattersley AT, Bowden DW, Collins FS, Atzmon G, Chambers JC, Spector TD, Laakso M, Strom TM, Bell GI, Blangero J, Duggirala R, Tai ES, McVean G, Hanis CL, Wilson JG, Seielstad M, Frayling TM, Meigs JB, Cox NJ, Sladek R, Lander ES, Gabriel S, Burtt NP, Mohlke KL, Meitinger T, Groop L, Abecasis G, Florez JC, Scott LJ, Morris AP, Kang HM, Boehnke M, Altshuler D, McCarthy MI. The genetic architecture of type 2 diabetes. Nature. 2016;536:41-7.

30. Stancáková A, Javorský M, Kuulasmaa T, Haffner SM, Kuusisto J, Laakso M. Changes in insulin sensitivity and insulin release in relation to glycemia and glucose tolerance in 6,414 Finnish men. Diabetes. 2009;58:1212-21.

31. Ray D, Chatterjee N. A powerful method for pleiotropic analysis under composite null hypothesis identifies novel shared loci between Type 2 Diabetes and Prostate Cancer. PLoS Genet. 2020;16:e1009218.

32. Andreou AP, Goadsby PJ. Therapeutic potential of novel glutamate receptor antagonists in migraine. Expert Opin Investig Drugs. 2009;18:789-803.

33. Jacquemin P, Lannoy VJ, Rousseau GG, Lemaigre FP. OC-2, a novel mammalian member of the ONECUT class of homeodomain transcription factors whose function in liver partially overlaps with that of hepatocyte nuclear factor-6. J Biol Chem. 1999;274:2665-71.

34. Yu J, Li D, Jiang H. Emerging role of ONECUT2 in tumors. Oncol Lett. 2020;20:328.

35. Solovieff N, Cotsapas C, Lee PH, Purcell SM, Smoller JW. Pleiotropy in complex traits: challenges and strategies. Nat Rev Genet. 2013;14:483-95.

36. Zhu Z, Wang X. Roles of cohesin in chromosome architecture and gene expression. Semin Cell Dev Biol. 2019;90:187-93.

37. Graf E, Puisac B, Ramos F, Schwarzmayr T, Gines MM, van Staveren T, van IJcken WFJ, Strom TM, Pié J, Watrin E, Kaiser FJ, Wendt KS. MAU2 and NIPBL Variants Impair the Heterodimerization of the Cohesin Loader Subunits and Cause Cornelia de Lange Syndrome. Cell Rep. 2020;31:107647. 
medRxiv preprint doi: https://doi.org/10.1101/2021.09.15.21263668; this version posted September 22, 2021. The copyright holder for this preprint (which was not certified by peer review) is the author/funder, who has granted medRxiv a license to display the preprint in perpetuity.

It is made available under a CC-BY-NC-ND 4.0 International license .

38. Friedrich C, Rinné S, Zumhagen S, Kiper AK, Silbernagel N, Netter MF, Stallmeyer B, Schulze-Bahr E, Decher N. Gain-of-function mutation in TASK-4 channels and severe cardiac conduction disorder. EMBO Mol Med. 2014;6:937-51.

39. He L, Ma Q, Wang Y, Liu X, Yuan Y, Zhang Y, Ou W, Liu L, Tan X, Wang X. Association of variants in KCNK17 gene with ischemic stroke and cerebral hemorrhage in a Chinese population. J Stroke Cerebrovasc Dis. 2014;23:2322-7.

40. Cosemans N, Vandenhove L, Maljaars J, Van Esch H, Devriendt K, Baldwin A, Fryns JP, Noens I, Peeters H. ZNF462 and KLF12 are disrupted by a de novo translocation in a patient with syndromic intellectual disability and autism spectrum disorder. Eur $\mathrm{J}$ Med Genet. 2018;61:376-83.

41. Weiss K, Wigby K, Fannemel M, Henderson LB, Beck N, Ghali N, Study DDD, Anderlid BM, Lundin J, Hamosh A, Jones MC, Ghedia S, Muenke M, Kruszka P. Haploinsufficiency of ZNF462 is associated with craniofacial anomalies, corpus callosum dysgenesis, ptosis, and developmental delay. Eur J Hum Genet. 2017;25:946-51.

\section{Figure legends:}

1. Figure 1: The Manhattan plot of the GWAS meta-analysis on headaches (N口= $\square 397,385)$. The dashed red line indicates the cut-off $P$ value of $5 \square \times \square 10^{-8}$.

2. Figure 2: The regional plots of the 4 new loci. Up left: the ONECUT2 region; Up right: the MAU2 region; Bottom left: the Intergenic region (Near KCNK17,6p21.2); Bottom right: the ZNF462 region.

3. Figure 3: Tissue expression results on 30 specific tissue types by GTEx in the FUMA. The dashed line shows the cut-off $P$ value for significance with Bonferroni adjustment for multiple hypothesis testing.

4. Figure 4: Tissue expression results on 53 specific tissue types by GTEx in the FUMA. The dashed line shows the cut-off $P$ value for significance with Bonferroni adjustment for multiple hypothesis testing. 

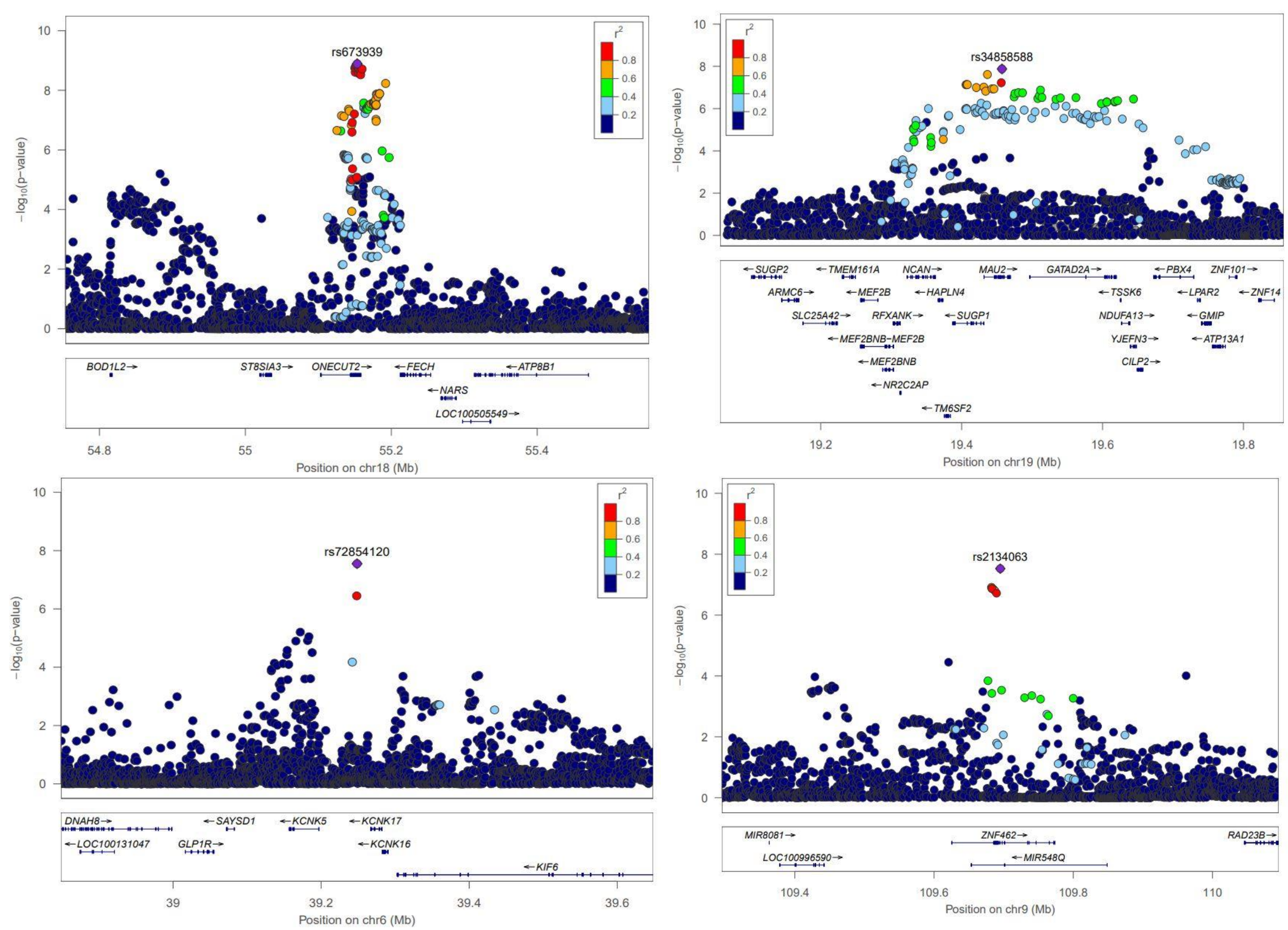


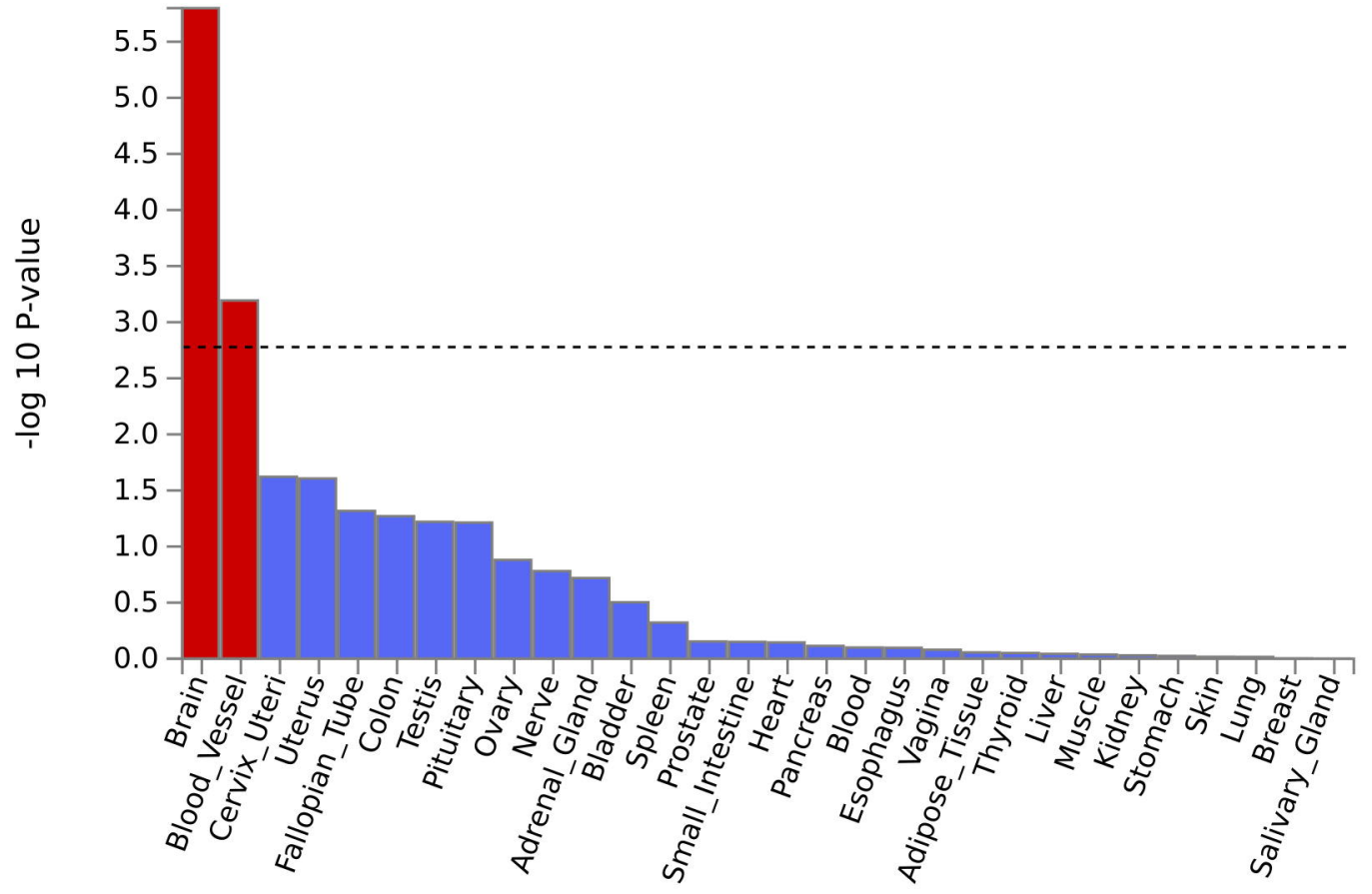




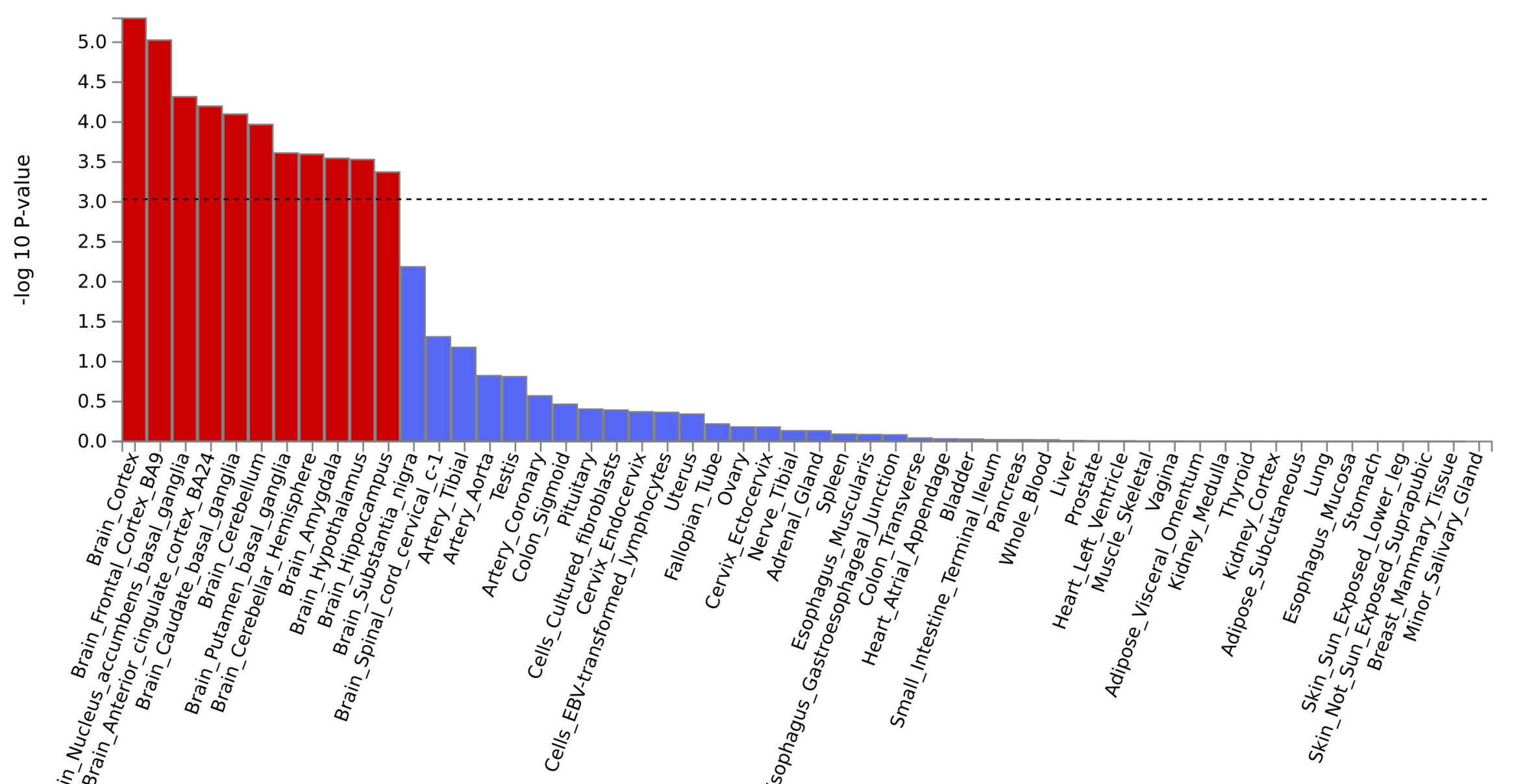




\begin{tabular}{|c|c|c|c|c|c|c|c|c|c|c|}
\hline Rank & Gene & Lead SNP & Chr & $\begin{array}{l}\text { SNP } \\
\text { position }\end{array}$ & $\begin{array}{l}\text { Locus } \\
\text { starts }\end{array}$ & $\begin{array}{l}\text { Locus } \\
\text { ends }\end{array}$ & $\begin{array}{l}\text { Z- } \\
\text { migraine }\end{array}$ & $\begin{array}{l}\text { Z- } \\
\text { headache }\end{array}$ & $\mathrm{P}$ & $\begin{array}{l}\text { Reported by } \\
\text { Gormley et al } \\
\text { and the locus } \\
\text { rank }\end{array}$ \\
\hline 1 & $\begin{array}{l}\text { LRP1-STAT6- } \\
\text { SDR9C7 }\end{array}$ & rs11172113 & 12 & 57527283 & 57244168 & 57629608 & -9.87 & -14.41 & $1.24 \times 10^{-62}$ & Yes (1) \\
\hline 2 & FHL5-UFL1 & rs9486715 & 6 & 97059769 & 96491180 & 97092478 & 7.16 & 11.64 & $6.57 \times 10^{-39}$ & Yes (3) \\
\hline 3 & PHACTR1 & rs9349379 & 6 & 12903957 & 12779759 & 12943066 & -7.51 & -7.87 & $4.62 \times 10^{-2 b}$ & Yes (6) \\
\hline 4 & TRPM8-HJURP & rs2362290 & 2 & 234825369 & 234753407 & 234874402 & -7.11 & -8.08 & $1.49 \times 10^{-24}$ & Yes (5) \\
\hline 5 & PRDM16 & rs10218452 & 1 & 3075597 & 3065568 & 3233631 & 8.83 & 5.86 & $7.70 \times 10^{-24}$ & Yes (2) \\
\hline 6 & MEF2D & rs2282286 & 1 & 156452870 & 156403681 & 156474929 & 6.21 & 6.68 & $6.00 \times 10^{-18}$ & Yes (7) \\
\hline 7 & $\begin{array}{l}\text { Intergenic (Near } \\
\text { TSPAN2-NGF) }\end{array}$ & rs12134493 & 1 & 115677946 & 115065179 & 115806438 & 6.14 & 6.37 & $7.48 \times 10^{-16}$ & Yes (4) \\
\hline 8 & $\begin{array}{l}\text { Intergenic (Near } \\
\text { ADAMTSL4- } \\
\text { ECM1) }\end{array}$ & rs6693567 & 1 & 150510660 & 150204405 & 150515021 & 4.47 & 6.95 & $7.16 \times 10^{-15}$ & Yes (28) \\
\hline 9 & $\begin{array}{l}\text { Intergenic (Near } \\
\text { GPR149) }\end{array}$ & rs34097149 & 3 & 154263175 & 154014284 & 154438050 & -4.89 & -6.42 & $2.80 \times 10^{-14}$ & Yes (19) \\
\hline 10 & $\begin{array}{l}\text { Intergenic (Near } \\
\text { FGF6) }\end{array}$ & rs10774231 & 12 & 4515374 & 4515374 & 4529169 & -5.49 & -5.86 & $3.82 \times 10^{-14}$ & Yes (9) \\
\hline 11 & $\begin{array}{l}\text { LINC02210- } \\
\text { CRHR1-MAPT }\end{array}$ & rs117368197 & 17 & 43715924 & 43463493 & 44865603 & -0.37 & 7.63 & $1.08 \times 10^{-13}$ & $\begin{array}{l}\text { No (reported } \\
\text { by Meng et } \\
\text { al) }\end{array}$ \\
\hline 12 & ASTN2 & rs10759844 & 9 & 119249326 & 119157030 & 119401227 & -4.62 & -6.34 & $1.44 \times 10^{-13}$ & Yes (13) \\
\hline 13 & SLC24A3 & rs4814864 & 20 & 19469817 & 19455203 & 19488952 & 7.03 & 3.32 & $2.39 \times 10^{-13}$ & Yes (8) \\
\hline 14 & CFDP1 & rs11149826 & 16 & 75435140 & 75304497 & 75516739 & -4.92 & -5.55 & $3.20 \times 10^{-12}$ & Yes (16) \\
\hline 15 & $\begin{array}{l}\text { PLEKHA1 } \\
\text { (ARMS2- } \\
\text { HTRA1) }\end{array}$ & rs78438709 & 10 & 124201071 & 124016160 & 124233181 & -2.59 & -6.83 & $1.41 \times 10^{-11}$ & Yes (35) \\
\hline 16 & MRVI1 & rs4909945 & 11 & 10673739 & 10655623 & 10699750 & -4.11 & -5.84 & $4.58 \times 10^{-11}$ & Yes (14) \\
\hline 17 & $\begin{array}{l}\text { Intergenic (Near } \\
\text { GJA1) }\end{array}$ & rs9490318 & 6 & 121860207 & 121782750 & 121860207 & 3.06 & 6.38 & $6.84 \times 10^{-11}$ & Yes (25) \\
\hline 18 & SUGCT & rs77410344 & 7 & 40410924 & 40360982 & 40477363 & 5.39 & 4.57 & $7.44 \times 10^{-11}$ & Yes (10) \\
\hline 19 & $\begin{array}{l}\text { Intergenic (Near } \\
\text { JAG1) }\end{array}$ & rs6040095 & 20 & 10680221 & 10658917 & 10698494 & 5.38 & 4.58 & $7.78 \times 10^{-11}$ & Yes (20) \\
\hline
\end{tabular}




\begin{tabular}{|c|c|c|c|c|c|c|c|c|c|c|}
\hline 20 & RNF213 & rs12943001 & 17 & 78238645 & 78235300 & 78269111 & -5.36 & -4.04 & $7.35 \times 10^{-10}$ & Yes (17) \\
\hline 21 & ONECUT2 & rs673939 & 18 & 55153266 & 55125438 & 55192245 & -4.05 & -5.24 & $1.29 \times 10^{-0 y}$ & No (new \\
\hline 22 & NOL4L & rs159058 & 20 & 31108108 & 31097877 & 31177986 & -4.14 & -5.11 & $1.68 \times 10^{-09}$ & $\begin{array}{l}\text { locus) } \\
\text { No (reported } \\
\text { by Meng et } \\
\text { al) }\end{array}$ \\
\hline 23 & $\begin{array}{l}\text { Intergenic (Near } \\
\text { ZCCHC2) }\end{array}$ & rs4941139 & 18 & 60162791 & 60159026 & 60206676 & 0.29 & 6.35 & $3.38 \times 10^{-0 y}$ & $\begin{array}{l}\text { No (reported } \\
\text { by Meng et } \\
\text { al) }\end{array}$ \\
\hline 24 & $\begin{array}{l}\text { Intergenic (Near } \\
\text { ZCCHC14) }\end{array}$ & rs8052831 & 16 & 87578039 & 87575332 & 87580855 & 5.72 & 2.98 & $3.80 \times 10^{-0 y}$ & Yes (22) \\
\hline 25 & PLCE1 & rs3891783 & 10 & 96015793 & 96009182 & 96069405 & -5.07 & -3.96 & $4.10 \times 10^{-0 y}$ & Yes (11) \\
\hline 26 & CARF & rs72928613 & 2 & 203839628 & 203639395 & 204196618 & -4.19 & -4.85 & $4.80 \times 10^{-0 y}$ & Yes (34) \\
\hline 27 & $\begin{array}{l}\text { Intergenic (Near } \\
\text { ITPK1) }\end{array}$ & rs28540738 & 14 & 93591673 & 93591673 & 93596315 & -4.63 & -4.43 & $4.95 \times 10^{-0 y}$ & Yes (27) \\
\hline 28 & CHRM4 & rs2067482 & 11 & 46406767 & 46330604 & 47237359 & -3.29 & -5.49 & $4.99 \times 10^{-0 y}$ & $\begin{array}{l}\text { No (reported } \\
\text { by Meng et } \\
\text { al) }\end{array}$ \\
\hline 29 & CAMK1D & rs10752269 & 10 & 12692902 & 12662552 & 12740543 & 0.81 & 6.22 & $7.11 \times 10^{-09}$ & $\begin{array}{l}\text { No (reported } \\
\text { by Meng et } \\
\text { al) }\end{array}$ \\
\hline 30 & MAU2 & rs34858588 & 19 & 19457235 & 19373944 & 19461676 & 3.59 & 5.10 & $1.33 \times 10^{-08}$ & No (new \\
\hline 31 & MYO1H & rs6606710 & 12 & 109848903 & 109848903 & 109850788 & 2.07 & 5.76 & $2.60 \times 10^{-08}$ & $\begin{array}{l}\text { No (reported } \\
\text { by Meng et } \\
\text { al) }\end{array}$ \\
\hline 32 & $\begin{array}{l}\text { Intergenic (Near } \\
\text { KCNK17) }\end{array}$ & rs72854120 & 6 & 39248533 & 39248092 & 39248533 & -2.68 & -5.49 & $2.81 \times 10^{-08}$ & $\begin{array}{l}\text { No (new } \\
\text { locus) }\end{array}$ \\
\hline 33 & ZNF462 & rs2134063 & 9 & 109695139 & 109682501 & 109695139 & 3.16 & 5.21 & $2.98 \times 10^{-08}$ & No (new \\
\hline 34 & $\begin{array}{l}\text { Intergenic (Near } \\
\text { CDKN2C) }\end{array}$ & rs7555006 & 1 & 51480258 & 50890634 & 51480258 & 1.67 & 5.82 & $3.59 \times 10^{-08}$ & $\begin{array}{l}\text { No (reported } \\
\text { by Meng et } \\
\text { al) }\end{array}$ \\
\hline 35 & $\begin{array}{l}\text { LOC101927995 } \\
\text { (Near TGFBR2) }\end{array}$ & rs6791480 & 3 & 30480559 & 30427287 & 30500279 & 3.96 & 4.58 & $3.81 \times 10^{-08}$ & Yes (26) \\
\hline 36 & TJP2 & rs7850547 & 9 & 71747208 & 71704350 & 71834600 & -3.47 & -4.95 & $4.09 \times 10^{-08}$ & $\begin{array}{l}\text { No (reported } \\
\text { by Meng et } \\
\text { al) }\end{array}$ \\
\hline 37 & NUFIP2 & rs8614 & 17 & 27588806 & 27564013 & 27588980 & 1.19 & 5.87 & $4.56 \times 10^{-08}$ & $\begin{array}{l}\text { No (reported } \\
\text { by Meng et }\end{array}$ \\
\hline
\end{tabular}




\begin{tabular}{lllllllllll}
\hline 38 & $\begin{array}{l}\text { Intergenic (Near } \\
\text { REST-SPINK2) }\end{array}$ & rs781669 & 4 & 57819794 & 57727311 & 57838999 & 2.83 & 5.31 & $4.67 \times 10^{-08}$ & Yl) \\
\hline
\end{tabular}

Chr: chromosome

The 4 new identified loci are shaded. The Z values (ratio of effect size to standard error) stand for the specific SNP effect contribution from each cohort.

The locus rank reported in final column is based on the Gormley et al's paper.

Table 1: The 38 loci generated by the GWAS meta-analysis study on self-reported headache and self-reported migraine 
medRxiv preprint doi: https://doi.org/10.1101/2021.09.15.21263668; this version posted September 22, 2021. The copyright holder for this preprint (which was not certified by peer review) is the author/funder, who has granted medRxiv a license to display the preprint in perpetuity.

It is made available under a CC-BY-NC-ND 4.0 International license .

\begin{tabular}{|c|c|c|c|c|c|c|c|}
\hline & & Effective & $23 a$ & $\mathrm{dMe}$ & UK & iobank & Joint \\
\hline New Locus (Chr) & Lead SNP & & $\begin{array}{l}\text { Beta } \\
\text { (se) }\end{array}$ & $P$ & $\begin{array}{l}\text { Beta } \\
\text { (se) }\end{array}$ & $P$ & $P$ \\
\hline $\begin{array}{l}\text { ONECUT2 } \\
(18 q 21.31)\end{array}$ & rs673939 & C & $\begin{array}{l}-0.04 \\
(0.01)\end{array}$ & $\begin{array}{c}4.88 \\
x \\
10^{-05}\end{array}$ & $\begin{array}{l}-0.0078 \\
(0.001)\end{array}$ & $\begin{array}{c}1.63 \\
x \\
10^{-07}\end{array}$ & $1.29 \times 10^{-09}$ \\
\hline $\begin{array}{l}\text { MAU2 } \\
(19 p 13.11)\end{array}$ & rs34858588 & $\mathrm{G}$ & $\begin{array}{l}0.067 \\
(0.019)\end{array}$ & $\begin{array}{c}3.53 \\
x \\
10^{-04}\end{array}$ & $\begin{array}{l}0.013 \\
(0.003)\end{array}$ & $\begin{array}{c}3.40 \\
x \\
10^{-07}\end{array}$ & $1.33 \times 10^{-08}$ \\
\hline $\begin{array}{l}\text { Intergenic (Near } \\
\text { KCNK17,6p21.2) }\end{array}$ & rs72854120 & C & $\begin{array}{l}-0.23 \\
(0.08)\end{array}$ & $\begin{array}{c}6.22 \\
x \\
10^{-03}\end{array}$ & $\begin{array}{l}-0.047 \\
(0.009)\end{array}$ & $\begin{array}{c}3.99 \\
x \\
10^{-08}\end{array}$ & $2.81 \times 10^{-08}$ \\
\hline $\begin{array}{l}\text { ZNF462 } \\
(9 q 31.2)\end{array}$ & rs2134063 & $\mathrm{G}$ & $\begin{array}{l}0.04 \\
(0.01)\end{array}$ & $\begin{array}{c}1.60 \\
x \\
10^{-03}\end{array}$ & $\begin{array}{l}0.0099 \\
(0.002)\end{array}$ & $\begin{array}{c}1.85 \\
x \\
10^{-07}\end{array}$ & $2.98 \times 10^{-08}$ \\
\hline
\end{tabular}

Table 2: The summary statistics of the 4 new loci of headaches 